sciendo Порівняльна професійна педагогіка 9(4)/2019 Comparative Professional Pedagogy 9(4)/2019

DOI: $10.2478 /$ rpp-2019-0033

PhD in Philology, Associate Professor, LARYSA KLOCHKO

A. S. Makarenko Sumy State Pedagogical University Address: 87 Romenska St., Sumy, 40000, Ukraine E-mail: Klochko0282@ukr.net

$\mathrm{PhD}$ in Pedagogy, Associate Professor, OLENA TERENKO

A. S. Makarenko Sumy State Pedagogical University Address: 87 Romenska St., Sumy, 40000, Ukraine E-mail: eterenko@ukr.net

\title{
SOME PECULIARITIES OF THE FIRST WOMEN'S COLLEGES FUNCTIONING IN THE USA
}

\begin{abstract}
The function of the first women's colleges in the USA is singled out. They expanded opportunities for women to get higher level of education, taking into account the fact that at that time women were not allowed to enter higher education establishments on equal footing with men. Some structural peculiarities of the first women's colleges are viewed. By educational level colleges for women in that period were subdivided into two-year colleges, four-year colleges and universities. Financing peculiarities of the first women's colleges in the USA are analysed. According to the source of financing colleges were private and public. The factors that led to the development of women's education are analysed. Insufficient number of teachers in schools and widespread printed literature led to the need of involvement women in higher education. Teachers thought that intellectual abilities of men and women were equal, because women were not in social deprivation, and should participate fully in the life of civil society after obtaining knowledge in educational institutions. Due to scientific and technological revolution a number of devices that allow women to save time for economic affairs was worked out and, in turn, for this reason women could focus more on gaining knowledge for mastering future profession. The goals of women's colleges establishment are analysed. Some teachers tried to train teachers, taking into account the shortage of teachers in schools due to expansion of the school network. Other teachers tried to give scientific and religious education and improve health of girls. The third group of teachers wanted to teach women self-education. The specifics of functioning of the first Catholic women's colleges is analysed. Catholic leaders raised the question of expanding the network of Catholic women's collegei due to insufficient number of religious teachers who have had some education level, because of the inability of church leaders to leave the church for educational services in colleges. In the USA, a peculiar feature of teaching in Catholic colleges was that the purpose of providing educational services was not only the development of intellectual abilities and training for future careers, but also spiritual development of students, which is the foundation of the Catholic faith.

Keywords: the USA, women's education, Catholic college, academy, college, function, purpouse, factor.
\end{abstract}

\section{АНОТАЦІЯ}

Виділено функцію перших жіночих коледжів в США. Вони розширювали можливості жінок у отриманні освітніх послуг вищого рівня, приймаючи до уваги 
sciendo Порівняльна професійна педагогіка 9(4)/2019 Comparative Professional Pedagogy 9(4)/2019

факт, щуо на той час жінки були позбавлені права вступати до вищих навчальних закладів на рівних засадах з чоловіками. Розглянуто структурні особливості перших жіночих коледжів. Відповідно до освітнього рівня навчальні заклади на той час поділялись на дворічні коледжі, чотирирічні коледжі та університети. Проаналізовано джерела фінансування перших жіночих коледжів. Відповіждно до джерел фінансування коледжі були державні та приватні. Проаналізовано фактори, щзо слугували розвитку жіночої освіти в США. Недостатня кількість учителів у школах та масове поширення друкованої літератури слугували потребою надання жінкам права отримувати вищу освіту. Учителі вважали, що інтелектуальні здібності жінок і чоловіків рівні, тому жінки мають приймати активну участь у громадському житті суспільства після здобуття освіти у вищих навчальних закладах. Завдяки науковій та технологічній революиї були винайдені прилади, які дозволяли жінкам зекономити час на виконанні хатніх справ, щзо дозволяло жінкам виділити час на оволодіння знаннями, необхідними для майбутньої професії. Проаналізовано иілі заснування жіночих коледжів в США. Деякі педагоги прагнули підготувати учителів, приймаючи до уваги факт недостатньої кількості учителів та розширення мережі шкіл. Інша група учителів прагнула надати наукову та релігійну освіту та покращити рівнеь здоров'я дівчат. Третя група педагогів прагнула навчити жінок займатись самоосвітою. Проаналізовано специфіку функціонування перших жіночих католицьких коледжівв США. Лідери католиџької церкви наголошували на необхідності розширення мережі жіночих католииьких коледжів, приймаючи до уваги факт недостатньої кількості віруючих учителів, оскільки служителі церкви не могли залишати церкву для надання освітніх послуг у коледжі. Характерною рисою жіночої освіти у католицьких коледжах було те, щзо педагогічний прочес був начілений не тільки на розвиток інтелектуальних здібностей та підготовку до майбутньої роботи, а й на духовний розвиток студентів, щзо є основою католицької віри.

Ключові слова: США, жіноча освіта, католицький коледж, академія, коледж, функиія, мета, фактор.

\section{INTRODUCTION}

At the beginning of the 21 st century there is an increasing role of women education in the development of modern society, because of socio-economic, scientific, technical and socio-cultural changes at global and local levels; understanding that education of women is one of the important tools of social development, factor of eliminating contradictions between increasing demands of modern era and modern paradigm of education. Women education gives the way for the entry of women in modern high-tech society and their adaptation to it, plays a leading role in the intellectual potential of society and preservation of cultural identity of the country, is an important mechanism of competitive state. Women education is deeply traditional, because it originates in ancient times and innovative, since it is based on the methodology of the gender, person-targeted and personalized approaches. The main organisations that conduct research in the sphere of women education in the USA are National Federation of Business and Professional Women's Clubs, National Association of Deans of Women and National Catholic education Association. We think that the study of features of women education in the United States is necessary for Ukraine, because our country still stands on the way of implementation gender approach in education. 
sciendo Порівняльна професійна педагогіка 9(4)/2019 Comparative Professional Pedagogy 9(4)/2019

THE AIM OF THE STUDY in the USA.

The paper aims to analyse peculiarities of the first women's colleges functioning

\section{THEORETICAL FRAMEWORK AND RESEARCH METHODS}

The analysis of scientific literature suggests that the US education system has always been in the field of Ukrainian researchers such as N. Bidyuk (2009), O. Ogienko (2014). Higher women's education was researched by such American scientists as J. Antler (2002), C. Farnham (2005). Gender aspect of education was a subject of research of such scientists L. Gordon (2000), P. Palmiery (2005), A. Thompsom (1993). History of women's education was analysed T. Woody (1999).

However, analysis of scientific literature makes it possible to say peculiarities of the first women' colleges functioning have not been the subject of systematic study and special analysis. To fulfill the aim of our research we will apply the following methods: analysis, synthesis, induction, deduction, analogy, comparative historical method, genetic method, problem-chronological method.

\section{RESULTS}

Analysing functioning of the first women's colleges that were founded in the middle of the 19th century, we can state that they expanded opportunities for women to get higher level of education, taking into account the fact that at that time women were not allowed to enter higher education establishments on equal footing with men. By educational level colleges for women in that period, were subdivided into in two-year colleges, fouryear colleges and universities. According to the source of financing colleges were private and public.

American scholar T. Woody pays attention to the fact that a number of social factors such as insufficient number of teachers in schools and widespread printed literature led to the need of involvement women in higher education. Teachers thought that intellectual abilities of men and women were equal, because women were not in social deprivation, and should participate fully in the life of civil society after obtaining knowledge in educational institutions (Woody, 1999).

The first schools that provided women the right to receive educational services were academies. Conducting comparative analysis of the views of teachers on the status of female education, we have found out that when the number of academies increased, the views of leading teachers were divided into two streams. The first group of teachers led by E. Willard, noted the need to reform content of education in women's academies, making it more academic. Other teachers, led by C. Beecher, suggested expanding educational offerings for women at colleges.

C. Beecher stated that academy did not have such libraries as colleges, which enrolled only men, for this reason women were deprived of the right to obtain more profound knowledge. Besides, educational process in academy was controlled only by teachers and principal, college curriculum was examined by community, which partly funded educational services. We consider it appropriate to pay attention to the fact that $\mathrm{C}$. Beecher stated that establishing of women's colleges is the basis for improving teaching, because college stuff is involved not only teaching but also in research work, which indicates a high professional level of teachers (Antler, 2002).

In the context of our study it is important to single out factors that led to the first women's colleges establishment. According to American researcher J. Antler school network expansion presupposed the fact that more women wanted to continue learning in colleges. In turn, expansion of school education has led to increased demand for teachers. 
sciendo Порівняльна професійна педагогіка 9(4)/2019 Comparative Professional Pedagogy 9(4)/2019

At the same time C. Farnham stressed that women were better teachers than men. Only a small number of men showed a desire to work in the sphere of education, because wages in this economic sector were the lowest. Secondly, expansion of printed literature motivated women to obtaining of education. Thirdly, due to scientific and technological revolution a number of devices that allow women to save time for economic affairs was worked out and, in turn, for this reason women could focus more on gaining knowledge for mastering future profession. In addition, after the Civil War economic sector in which women have been involved has expanded: women were working in agriculture, as seamstress, haberdashery sellers and teachers. Despite the fact that the economic sector in which women were involved, expanded slowly, still a need for additional educational services was constantly growing.

Results of the study show that female college founders had diverse goals of their establishment. Some teachers tried to train teachers, taking into account the shortage of teachers in schools due to expansion of the school network. Other teachers tried to give scientific and religious education and improve health of girls. The third group of teachers wanted to teach women self-education. Some teachers from male colleges were against the opening of women's colleges. For example, C. Eliot, president of Harvard's college, considered that intellectual capacity of women is worse than mental abilities of men, for this reason it would be difficult for women to study in college. Although C. Eliot said that woman's body is not built like the body of her husband, so intensive intellectual activity can weaken her health, for this reason teaching methods for women should be different from teaching methods for men. We found out that some doctors were of the opinion that higher education could harm women to have healthy babies, as some women who studied in colleges, had diseases of nervous system and bleeding. Public attitude to higher women's education has been mixed, because some researchers reported that women's access to higher education may reduce the number of marriages. Moreover, historians paid attention to the fact that the reduction in the number of marriages can lead to reduced fertility.

Historians have several points of view regarding the date of the founding of the first women's college. Thus, G. Lin claims that in 1836 Georgian college was established, in which women were provided education at the same level as in men's colleges. Although P. Palmiery claims that Mary Sharp college, founded in 1851, was the first female educational institution, where the study of Greek and Latin were included in the four-year course (Palmiery, 2005).

First Catholic colleges appeared in the United States in the end of XVIII century. A. Thompson stated that Catholic leaders raised the question of expanding the network of Catholic women's college due to insufficient number of religious teachers who had some education level, because of the inability of church leaders to leave the church for educational services in colleges. The first four-year Catholic college Notre Dame was founded in Maryland in 1899. A representative analysis of statistical data shows that every year dynamics testified increase in the number of Catholic four-year colleges. So in 1905, 4 colleges were established, from 1905 to 1915 years - 14 colleges, from 1915 to $1925-37$ college, from 1925 to 1930 - 19 colleges. In 1955 there were 116 Catholic colleges in the United States of America. Currently, the most famous Catholic colleges are Trinity college in Washington, Mary's college in Indiana and St. Catherin's college in the state of Minnesota (Thompson, 1993).

The peculiarity of teaching in Catholic colleges was that the purpose of providing educational services was not only the development of intellectual abilities and training for future careers, but also spiritual development of students, which is the foundation of the Catholic faith. For the first time in 1931 in college of Merry Grove a number of subjects 
sciendo Порівняльна професійна педагогіка 9(4)/2019 Comparative Professional Pedagogy 9(4)/2019

was introduced, which later had to help women become skilled church leaders, namely, education, social work, basics of banking, journalism and music.

\section{CONCLUSIONS}

Women's education paves the way for the entry of women in modern high-tech society and their adaptation to it, plays a leading role in the intellectual potential of society and preservation of cultural identity of the country, is an important mechanism of competitive state; women's education is deeply traditional, because it originates in ancient times and innovative, as based on the methodology of the gender, person-oriented approaches. School network expansion has meant that more women wanted to continue learning in colleges. Expansion of school education has led to increased demand for teachers; wide dissemination of printed literature motivated women to obtaining of education; due to scientific and technological revolution a number of devices was created that allow women to save time for economic affairs and, in turn, focus more on gaining knowledge for mastering future profession. Women's colleges founders had diverse goals of their establishment: teacher training, provision of scientific and religious education, development of skills required for self-employment. Leaders of the Catholic church emphasized the need to expand the network of Catholic women's colleges due to lack of religious teachers. A peculiar feature of teaching in Catholic colleges was that the purpose of providing educational services was not only the development of intellectual abilities and training for future career, but also spiritual development of students, which is the foundation of the Catholic faith.

Future research work will be aimed at analysis of peculiarities of women's colleges functioning at the beginning of the 21 st century.

\section{REFERENCES}

1. Antler, J. (2002). Culture, Service and Work: Changing Ideals for Higher Education for Women. Lexington: Helth \& Co.

2. Bidyuk, N. (2009). Profesiyne navchannya bezrobitnyh u SShA: teoriya $i$ praktyka. Khmelnytskyi: HMTSNTEI.

3. Farnham, C. (2005). The Education of the Southern Belle: Higher Education and Student Socialization in the Antebellum South. New York: New York University Press.

4. Gordon, L. (2000). From Seminary to University: Gender and Higher Education in the Progressive Era. New Haven: Yale University Press.

5. Ogienko, O. (2014). Andragogichna model navchannya: amerikanskyi kontekst. Kyiv: Tsentr Uchbovoi Literatury.

6. Palmiery, P. (2005). In Adamless Eden: The Community of Faculty Women at Wellesley. New Haven: Yale University Press.

7. Thompson, A. (1993). Progressivism and the Higher Education of Southern Women. North Carolina Historical Review, 3, 317.

8. Woody, T. (1999). History of Women's Educationin the United States. New York: The Science Press.

9. Yee, S. (2002). Black Women Abolitionists: A Study in Activism. Knoxville: University of Tennessee Press.

10. Zaeske, S. (2003). Signatures of Citizenship: Petitioning, Antislavery and Women's Political Identity. Chapel Hill \& London: The University of North Carolina Press. 